\title{
The Pragmatic Introduction and Expression of Microbial Transgenes in Plants
}

\author{
Sajid Ali, Soon-Ki Park, and Won-Chan Kim* \\ School of Applied Biosciences, Kyungpook National University, Daegu 41566, Republic of Korea
}

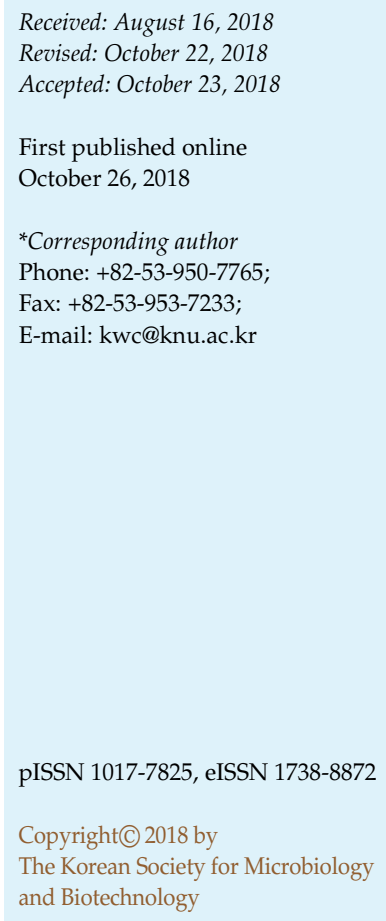

Several genetic strategies have been proposed for the successful transformation and expression of microbial transgenes in model and crop plants. Here, we bring into focus the prominent applications of microbial transgenes in plants for the development of disease resistance; mitigation of stress conditions; augmentation of food quality; and use of plants as "bioreactors" for the production of recombinant proteins, industrially important enzymes, vaccines, antimicrobial compounds, and other valuable secondary metabolites. We discuss the applicable and cost-effective approaches of transgenesis in different plants, as well as the limitations thereof. We subsequently present the contemporary developments in targeted genome editing systems that have facilitated the process of genetic modification and manifested stable and consumer-friendly, genetically modified plants and their products. Finally, this article presents the different approaches and demonstrates the introduction and expression of microbial transgenes for the improvement of plant resistance to pathogens and abiotic stress conditions and the production of valuable compounds, together with the promising research progress in targeted genome editing technology. We include a special discussion on the highly efficient CRISPR-Cas system helpful in microbial transgene editing in plants.

Keywords: Microbial transgenes, model and crop plants, transgenesis, plants as bioreactors, targeted editing genome technology, CRISPR-Cas

\section{Introduction}

Current trends and developments in plant biotechnology have paved the way for the expression of potentially valuable genes from microorganisms into different plants. Since three decades, remarkable developments in the identification, isolation, transfer, and expression of genes of microbial origin have supported the expression of traits for disease resistance, abiotic stress tolerance, and the synthesis of specific proteins and secondary metabolites in various plant species. With respect to the increasing global demands of food, medicine, and bioactive secondary metabolites, plant biotechnologists are enthusiastic to optimize the expression of genes of interest isolated from microbes inside model as well as crop plants. Similarly, modern agriculturists have also focused on the healthy growth of various crop plants, including vegetables, fruits, and cereals. The widespread use of agrochemicals and classical hybridization methods have contributed to our present-day agriculture, but these strategies are facing noticeable limitations in the form of insufficient efficacy and species constraints.

However, recombinant DNA technology helps overcome these limitations, and genes of choice can be inserted into various plants for specific traits in sexually incompatible plant species by artificial horizontal gene transfer. Moreover, genetic engineering techniques are applied to express microbial transgenes in plants for the achievement of various goals, i.e., the activation of plant defense response, antimicrobial effects, stress tolerance, and high yields. In addition, plant biotechnologists are also dedicated to utilizing plants as "bioreactors" and harvesting recombinant proteins, industrially important enzymes, vaccines, and other valuable bioactive secondary metabolites at a low 
cost and with easily manageable downstream processing. Similarly, model plants have been exploited for the screening of potentially useful genes and their role in physiological and genetic processes, which can be easily deciphered in model plants; in plant biotechnology, these plants are also known as "living laboratories" [1,2].

Numerous methods have been proposed for the transfer of genes of interest into plants. Initially, the scientific community had focused considerably on the Ti-plasmid of Agrobacterium tumefaciens as a vehicle for gene transfer, and several genetic transformation protocols have been established for different plants. The extensive use of the Tiplasmid of $A$. tumefaciens helped transfer a number of useful genes isolated from animals, fungi, bacteria, and viruses for expression in plants. Broothaerts et al. (2005) reported that Agrobacterium is closely related to Rhizobium and should be reclassified as Rhizobium radiobacter [3]. Several other efficient and novel transformation systems have also been developed for model and crop plants, and recent studies are suggesting that foreign DNA can be stably incorporated into plant protoplasts via direct gene transfer, without using A. tumefaciens (Fig. 1).
Several studies have referred to the successful introduction and expression of microbial transgenes in plants (Table 1). Avirulence (avrPto) genes isolated from Pseudomonas syringae and inserted into Solanum lycopersicum stimulate the defense mechanism and demonstrate resistance to pathogen toxins [4]. Some other valuable genes also isolated from microorganisms have revealed antimicrobial effects and disease resistance in plants. The important model and crop plants that have been genetically modified include Arabidopsis [5], tobacco [6], rice [7], citrus [8], and tomato [9] whereas the strategies for developing disease-resistant transgenic plants include transgenesis of microbial genes in plants that regulate defense mechanisms, genes signaling for pathogen recognition, and genes encoding for detoxification $[2,10]$. Genes of interest have been screened from fungi, viruses, and bacteria and have been effectively utilized to enhance the desirable traits in genetically modified model and crop plants.

Correspondingly, microbial transgenes in plants have revealed fruitful effects by mitigating abiotic stress conditions, e.g., in waterlogged conditions, the growth and productivity of plants is greatly affected by ethylene stress,

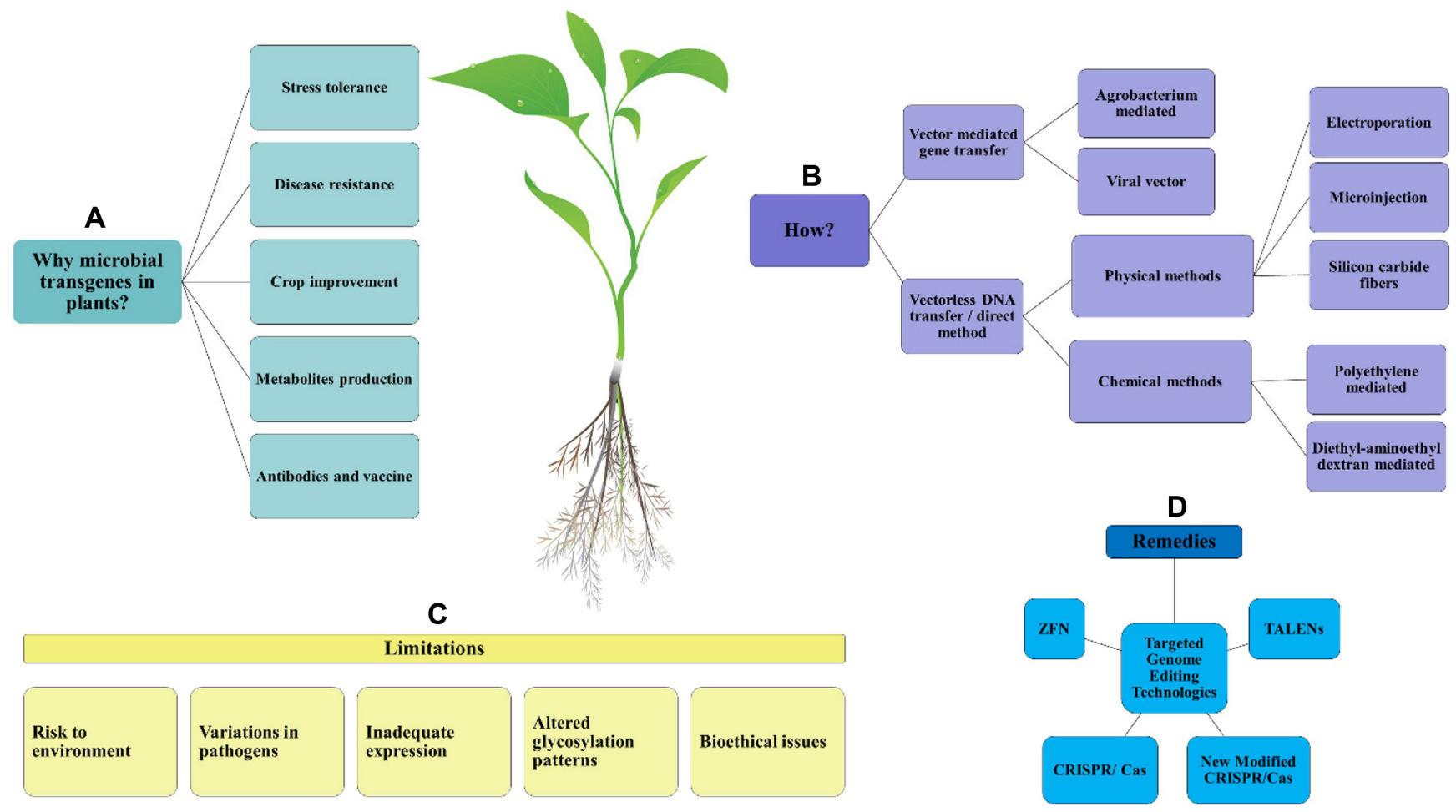

Fig. 1. Demonstrates the expressions of microbial transgenes in model and crop plants.

(A) Microbial transgenes expression in transgenic plants conferred different traits. (B) Methods of microbial transgenesis and expression in plants. (C) Limitations of microbial transgenes in plants. (D) Novel procedures as remedies for public concerns on genetically modified plants and their products. 
Table 1. Microbial transgenes expression in transgenic plants for a variety of purposes.

\begin{tabular}{|c|c|c|c|c|}
\hline Microbe & Gene of interest & Importance / Purpose & Transgenic Plant & Reference \\
\hline \multicolumn{5}{|c|}{ Microbial transgenes in plants: their antimicrobial products and activation of plant defense } \\
\hline Brevibacterium linens & BlMGL gene & $\begin{array}{l}\text { Resistance to nematode attacks Tylenculus } \\
\text { semipenetrans }\end{array}$ & Carrizo citrange & $\begin{array}{l}\text { Castillo et al., } \\
2017[30]\end{array}$ \\
\hline Bacillus thuringiensis & cry $1 A b$ gene & $\begin{array}{l}\text { Resistance against insects and white rust } \\
\text { disease }\end{array}$ & $\begin{array}{l}\text { Chrysanthemum } \\
\text { morifolium }\end{array}$ & $\begin{array}{l}\text { Ichikawa et } \\
\text { al., } 2015[96]\end{array}$ \\
\hline $\begin{array}{l}\text { Trichoderma } \\
\text { harzianum }\end{array}$ & $\beta-1,3-$ glucanase gene bgn13.1 & $\begin{array}{l}\text { Increases tolerance to crown rot diseases but } \\
\text { interferes with plant growth }\end{array}$ & Strawberry & $\begin{array}{l}\text { Mercado et al., } \\
2015 \text { [95] }\end{array}$ \\
\hline Bacillus thuringiensis & $\begin{array}{l}\text { modified cry1Ac and } \\
\text { cry1I-like gene }\end{array}$ & Insect resistance & Rice & $\begin{array}{l}\text { Yang et al., } \\
2014 \text { [7] }\end{array}$ \\
\hline $\begin{array}{l}\text { Trichoderma } \\
\text { harzianum }\end{array}$ & chit42 & $\begin{array}{l}\text { Resistance to Fusarium wilt and other } \\
\text { fungal diseases }\end{array}$ & Banana & $\begin{array}{l}\text { Hu et al., } 2013 \\
{[94]}\end{array}$ \\
\hline $\begin{array}{l}\text { Xanthomonas } \\
\text { axonopodis }\end{array}$ & pthA-nls & Resistance to citrus canker disease & $\begin{array}{l}\text { Sweet orange Citrus } \\
\text { sinensis L. }\end{array}$ & $\begin{array}{l}\text { Yang et al., } \\
2011[8]\end{array}$ \\
\hline $\begin{array}{l}\text { Trichoderma } \\
\text { harzianum }\end{array}$ & chit42 gene & $\begin{array}{l}\text { Resistance against fungal infection, } \\
\text { production of reactive oxygen species (ROS), } \\
\text { systemic acquired resistance (SAR) and } \\
\text { induced systemic resistance (ISR) }\end{array}$ & Lemon & $\begin{array}{l}\text { Gentile et al., } \\
2007 \text { [39] }\end{array}$ \\
\hline Vibrio cholerae & Cholera toxin B subunit gene & $\begin{array}{l}\text { High levels of CTB accumulation and } \\
\text { assembly of functional oligomers in } \\
\text { chloroplasts. } \\
\text { Control of human and animal diseases }\end{array}$ & Tobacco & $\begin{array}{l}\text { Daniell et al., } \\
2001[66]\end{array}$ \\
\hline $\begin{array}{l}\text { Pseudomonas } \\
\text { fluorescence }\end{array}$ & MF3 gene & $\begin{array}{l}\text { Enhanced resistance against fungal } \\
\text { pathogens }\end{array}$ & Carrot & $\begin{array}{l}\text { Baranski et al., } \\
2007 \text { [110] }\end{array}$ \\
\hline $\begin{array}{l}\text { Pseudomonas } \\
\text { syringae }\end{array}$ & avrPto gene & $\begin{array}{l}\text { Stimulate defense response, resistance to } \\
\text { bacteria and viruses }\end{array}$ & Tomato & $\begin{array}{l}\text { Tobias et al., } \\
1999[4]\end{array}$ \\
\hline Trichoderma virens & cht42 gene & For enhanced sheath blight resistance & Rice & $\begin{array}{l}\text { Shah et al., } \\
2009 \text { [115] }\end{array}$ \\
\hline Phytophthora cryptogea & $\begin{array}{l}\text { Pathogen inducible tobacco } \\
\text { hsr203J gene promoter and } \\
\text { Phytophthora cryptogea } \\
\text { gene encoding Cryptogein }\end{array}$ & $\begin{array}{l}\text { Hypersensitive response and nonspecific } \\
\text { disease resistance }\end{array}$ & Tobacco & $\begin{array}{l}\text { Keller et al., } \\
1999[107]\end{array}$ \\
\hline \multicolumn{5}{|c|}{ Microbial transgenes in plants for abiotic stress mitigation and enhancement of food quality } \\
\hline $\begin{array}{l}\text { Saccharomyces } \\
\text { cerevisiae }\end{array}$ & HAL1 gene & Improves salt tolerance & Tomato & $\begin{array}{l}\text { Gisbert et al., } \\
2000[102]\end{array}$ \\
\hline Escherichia coli & bet $A$ gene & Drought tolerance & Cotton & $\begin{array}{l}\text { Lv, S et al., } \\
2007[108]\end{array}$ \\
\hline $\begin{array}{l}\text { Arthrobacter } \\
\text { globiformis }\end{array}$ & $\operatorname{cod} A$ gene & Tolerance to salt and water stresses & Tomato & $\begin{array}{l}\text { Goel et al., } \\
2011 \text { [116] }\end{array}$ \\
\hline $\begin{array}{l}\text { Pseudomonas putida } \\
\text { strain UW4 }\end{array}$ & acdS gene & $\begin{array}{l}\text { For the production of 1-aminocyclopropane- } \\
\text { 1-carboxylate (ACC) deaminase to alleviate } \\
\text { stress ethylene }\end{array}$ & Brassica napus & $\begin{array}{l}\text { Sergeeva et al., } \\
2006[48]\end{array}$ \\
\hline Escherichia coli & betA gene & Chilling tolerance & Maize & $\begin{array}{l}\text { Quan et al., } \\
2004[14]\end{array}$ \\
\hline $\begin{array}{l}\text { Arthrobacter } \\
\text { globiformis }\end{array}$ & $\operatorname{cod} A$ gene & Salt stress tolerance & $\begin{array}{l}\text { Rice } \\
\text { (Basmati 1) }\end{array}$ & $\begin{array}{l}\text { Mohanty et } \\
\text { al., } 2002 \text { [100] }\end{array}$ \\
\hline Aspergillus niger & phytase gene & $\begin{array}{l}\text { Degrades the phosphorus storage compound } \\
\text { phytate and improves feed quality }\end{array}$ & Soybean & $\begin{array}{l}\text { Li et al., } 1997 \\
\text { [103] }\end{array}$ \\
\hline $\begin{array}{l}\text { Pseudomonas sp. } \\
\text { strain ADP }\end{array}$ & Modified bacterial atzA gene & Biodegradation of atrazine herbicides & $\begin{array}{l}\text { Alfafa, tobacco, } \\
\text { Arabidopsis thaliana }\end{array}$ & $\begin{array}{l}\text { Wang et al., } \\
2005[117]\end{array}$ \\
\hline
\end{tabular}


Table 1. Continued.

\begin{tabular}{|c|c|c|c|c|}
\hline Microbe & Gene of interest & Importance / Purpose & Transgenic Plant & Reference \\
\hline \multicolumn{5}{|c|}{ Microbial transgenes in plants for the production of beneficial enzymes, antibodies and vaccines } \\
\hline $\begin{array}{l}\text { Sulfolobus solfataricus } \\
\text { Alicyclobacillus } \\
\text { acidocaldarius }\end{array}$ & $\begin{array}{l}\text { endoglucanase (endo) gene } \\
\text { endo- } \beta-1,4-x y l a n a s e(x y n)\end{array}$ & $\begin{array}{l}\text { For greater expression of thermostable } \\
\text { cellulolytic enzymes for the hydrolysis of } \\
\text { industrially-pretreated Arundo donax L. } \\
\text { biomass }\end{array}$ & Nicotiana tabacum & $\begin{array}{l}\text { Castiglia et al., } \\
2016 \text { [6] }\end{array}$ \\
\hline Pyrococcus furiosus & $\beta$-glucosidase (celB) gene & & & \\
\hline $\begin{array}{l}\text { Clostridium } \\
\text { thermocellum }\end{array}$ & $x y n A 1$ gene & $\begin{array}{l}\text { Xylanases have potential applications in } \\
\text { industry and agriculture }\end{array}$ & Rice & $\begin{array}{l}\text { Kimura et al., } \\
2003[101]\end{array}$ \\
\hline Vibrio cholerae & CTB gene & Mucosal vaccine development & Oryza sativa & $\begin{array}{l}\text { Nochi et al., } \\
2007[98]\end{array}$ \\
\hline Escherichia coli & $\begin{array}{l}\text { Heat-labile enterotoxin } \\
\text { subunit (LT-B) }\end{array}$ & Oral immunization, antigen production & Tobacco, potato & $\begin{array}{l}\text { Haq et al., } \\
1995[104]\end{array}$ \\
\hline Vibrio cholerae & $\begin{array}{l}\text { CTB subunit fused with } \\
\text { AMA1 and MSP1 }\end{array}$ & Immunity against cholera and malaria & $\begin{array}{l}\text { Lettuce and tobacco } \\
\text { chloroplasts }\end{array}$ & $\begin{array}{l}\text { Davoodi-Semir } \\
\text { omi et al., } 2010 \\
{[114]}\end{array}$ \\
\hline Hepatitis B virus & $\begin{array}{l}\text { gene (adr subtype) } \\
\text { encoding the hepatitis B } \\
\text { surface antigen (HBsAg) }\end{array}$ & Plant-based edible vaccine development & $\begin{array}{l}\text { Lycopersicon } \\
\text { esculentum }\end{array}$ & $\begin{array}{l}\text { Guan et al., } \\
2012[9]\end{array}$ \\
\hline Dengue virus & $\begin{array}{l}\text { cDNA encoding DV } \\
\text { envelop protein }\end{array}$ & $\begin{array}{l}\text { Plant-based vaccines production against } \\
\text { dengue virus }\end{array}$ & Nicotiana benthamiana & $\begin{array}{l}\text { Martínez et } \\
\text { al., } 2010 \text { [99] }\end{array}$ \\
\hline \multicolumn{5}{|c|}{ Microbial transgenes for the production of secondary metabolites in transgenic plants } \\
\hline E. coli XL1Blue & ubiC gene & $\begin{array}{l}\text { 4-hydroxybenzoic acid glucosides } \\
\text { accumulation }\end{array}$ & $\begin{array}{l}\text { Solanum tuberosum } \mathrm{L} \text {. } \\
\text { Nicotiana tabacum } \mathrm{L} \text {. }\end{array}$ & $\begin{array}{l}\text { Kohle et al., } \\
2003 \text { [105] }\end{array}$ \\
\hline Erwinia uredowora & $\begin{array}{l}\text { Phytoene synthase gene } \\
(\operatorname{crtB})\end{array}$ & 50 -fold increase in carotenoids accumulation & Brassica napus & $\begin{array}{l}\text { Shewmaker et } \\
\text { al., 1999 [72] }\end{array}$ \\
\hline $\begin{array}{l}\text { P. fluorescens strain } \\
\text { Pf-5 }\end{array}$ & prn operon & Pyrrolnitrin (PLN) & Solanum lycopersicum & $\begin{array}{l}\text { Mozes-Koch } \\
\text { et al., } 2012 \\
{[109]}\end{array}$ \\
\hline Bacillus thuringiensis & (Bt) cry $2 A a 2$ operon & $\begin{array}{l}\text { Increased expression of the accumulated } \\
\text { insecticidal proteins: cuboidal crystals }\end{array}$ & Tobacco chloroplasts & $\begin{array}{l}\text { De Cosa et al., } \\
2001[110]\end{array}$ \\
\hline Escherichia coli & ubiC gene & $\begin{array}{l}\text { Accumulation of 4-hydroxybenzoate } \\
\text { glucosides }\end{array}$ & Tobacco & $\begin{array}{l}\text { Siebert et al., } \\
1996[106]\end{array}$ \\
\hline $\begin{array}{l}\text { Brevundimonas sp., } \\
\text { strain SD212 }\end{array}$ & $\begin{array}{l}\mathrm{CrtW} \text { gene } \\
\mathrm{Crt} Z \text { gene }\end{array}$ & Astaxanthin biosynthesis & Tobacco leaves & $\begin{array}{l}\text { Hasunuma et } \\
\text { al., 2008 [112] }\end{array}$ \\
\hline $\begin{array}{l}\text { Pantoea ananatis } \\
\text { Brevundimonas sp. } \\
\text { strain SD212 } \\
\text { Paracoccus sp. strain } \\
\text { N81106 }\end{array}$ & $\begin{array}{l}c r t E, \operatorname{crt} B, \operatorname{crtI} \operatorname{crt} Y, \operatorname{crt} Z \text { and } \\
\operatorname{crt} W \text { genes }\end{array}$ & Carotenoid biosynthesis & $\begin{array}{l}\text { Lilium } \times \text { formolongi } \\
\text { both calli and leaves }\end{array}$ & $\begin{array}{l}\text { Azadi } \text { et al., } \\
2010[113]\end{array}$ \\
\hline
\end{tabular}

while the bacterial acdS gene, which encodes ACC deaminase, mitigates flooding stress damage in transgenic plants by alleviating ethylene stress in plant tissues. Transgenic canola and tomato containing the bacterial acdS gene revealed increased biomass under flooding conditions [11, 12]. Similarly, Bordas et al. (1997) used Agrobacteriummediated gene transfer and isolated the $H A L_{1}$ gene from yeast (Saccharomyces cerevisiae) transferred to melon plants, which greatly mitigated the adverse effect of salt stress [13]. Quan et al. (2004) isolated and transferred the bet $A$ gene from Escherichia coli into the maize inbred DH4866 via Agrobacterium-mediated transformation for the synthesis of glycinebetaine for improved chilling tolerance [14]. Moreover, a number of microbial transgenes have been expressed in 
Arabidopsis, alfalfa, and tobacco to study intron splicing, mitotic inducers, and the activities of different enzymes. Besides this, plant biotechnologists are greatly interested in the production of cost-effective, industrially valuable enzymes inside plant tissues. In the mid-1980s, antibodies were first reported in plants. Tacket et al. (1998) used potato plants harboring a gene derived from pathogenic bacteria, and the antigenic proteins produced in transgenic potato plants retained prominent immunogenic properties. Thereafter, several immune-therapeutic products were successfully reported in different plants $[15,16]$.

However, the lack of public acceptance of transgenic crop plants has hindered the consumption of genetically modified plants and their products owing to the presence of antibiotic-resistant genes. In the last two decades, researchers have developed various approaches for the production of marker-free transgenic plants [17]. The recent advancements and developments in biotechnological procedures are revolutionizing recombinant DNA technology and simultaneously overcoming public reservations. Several microbial genes of interest have been expressed in plants for the production of modified and novel plant traits [18]. However, the concerns of the public regarding the acceptance of genetically modified crops has hindered the commercialization of genetically modified varieties. The progress in targeted genome editing technology (CRISPR/ Cas) is greatly contributing to gene knockouts and gene replacement in transgenic plant varieties [19, 20], while antibiotic-resistance, marker-free selection systems are also helpful in the excision of marker genes. These procedures will certainly contribute to expedite the process of commercial release of genetically modified plants and their products. Moreover, almost any microbial gene useful for plant productivity, disease resistance, or production of specific enzymes will soon be available in the market for successful transgenic plants and their desired products [17, 18]. In this review, the introduction and expression of microbial transgenes and their potential applications in model and crop plants are discussed, and the promising research progress in targeted genome editing technology, which is helpful in microbial transgenes editing in plants, is briefly discussed as well.

\section{Manifestation of Microbial Transgenes in Plants}

Transgenesis has demonstrated significant success in plant biotechnology, and various strategies have been suggested to genetically modify plants and enhance resistance to biotic and abiotic stress conditions, increase the productivity of crops, and produce non-plant proteins and industrially important enzymes. Functional genomics has paved the way for cloning and expression of microbial transgenes and has aided in understanding how plants cope with diseases. To date, different strategies have been followed to stably express microbial transgenes in plants to enhance resistance to pathogens and adverse environmental conditions and synthesize desirable products (Fig. 1, Table 1).

\section{Microbial Transgenes in Plants and Pathogen Resistance}

Some plant diseases can be highly destructive, leading to large-scale economic losses. Globally, plant pathogenic infections are responsible for $30-40 \%$ reduction in crop productivity, and losses to the tune of about 40 billion dollars have been estimated per annum. Plant pathogens such as bacteria, fungi, and viruses cause different diseases and are responsible for major plant losses, while the world's growing population requires efficient management and effective control of plant pathogenic diseases [21, 22]. Microbial genes have been expressed in plants, enhancing the defense response of the plants. Some plants with microbial transgenes synthesize transgenic compounds, which directly improve the antimicrobial activity of the plants. Meanwhile, some transgenes activate plant defense mechanisms and respond to pathogen toxins to protect the plant from adverse effects (Table 1).

Antimicrobial and insecticidal effects of microbial transgenes in plants. In the last 30 years, a substantial number of articles have been published on genetic engineering of different plant species with the objective of conferring resistance to viral, bacterial, and fungal infections. In this section, we report some prominent examples of these studies. Antimicrobial proteins are the key players in signal transduction and response, which are encoded by specific genes and are effective against a broad range of targets. Recently many such genes have been identified, while some important genes have been tested transgenically in different plant species to improve disease resistance. Chitinases, encoding genes of microbial origin, have been reported in different studies. These enzymes protect plants from the attack of fungal pathogens by degrading the chitin present in the fungal cell wall. The overexpression of the endochitinase gene in transgenic potato leads to higher levels of chitinases, which significantly inhibit the growth of phytopathogenic fungi such as Alternaria solani [23, 24]. Moreover, the overexpression of pathogenesis-related proteins is the most widely used transgenic approach in the enhancement of resistance against different pathogenic fungi [25]. Initially, a bacterial 
chitinase gene (chiA) was reported by Jones et al. (1988) from Serratia marcescens for chitinase expression in transgenic tobacco leaves [26], while Dehestani et al. (2010) evaluated the expression and antifungal activity of the Bacillus pumilus SG2 chitinase gene (ChiS) in Arabidopsis plants [23]. Similarly, Kahlon et al. (2017) reported the expression of antifungal genes in transgenic Pisum satioum, which did not affect the root colonization of non-target organisms, while significantly halting the deleterious effect of targeted pathogens [27].

Pathovars of the rod-shaped, gram-negative bacterium Pseudomonas syringae produce toxins (tabtoxin), which cause chlorosis in different plant species, while these bacteria have also developed a mechanism for self-protection from the adverse effects of tabtoxin. The enzyme glutamine synthetase is produced by the $t$ tr gene of $P$. syringae, which inactivates tabtoxin and protects the bacterium. The ttr gene has been cloned and expressed in the tobacco plant, which shows complete resistance to bacterial pathogenicity [28]. Similarly, in a target-specific mechanism, the bacterium $P$. syringae pv. phaseolicola synthesizes ornithine carbamoyltransferase, which is involved in arginine biosynthesis and is resistant to its own phaseolotoxin. The corresponding gene $(\arg K)$ has been cloned and used to transform bean plants, which appeared to be totally resistant to infection by P. syringae [29]. According to Castillo et al. (2017), the transgene BlMGL of Brevibacterium linens revealed resistance to nematode attacks (Tylenchulus semipenetrans) in Carrizo citrange [30]. More than 50\% of plant diseases are caused by fungi, with the remaining diseases being caused by bacteria, viruses, etc. In 1986, plant biotechnologists used viral coat proteins and produced transgenic virus-resistant tobacco plants. Since then, several plants have been genetically modified for the successful expression of viral coat proteins and have been reported to show high levels of resistance in comparison with untransformed plants. Furthermore, viral genome and genome-replicating proteins were also exploited and considered potential targets for genetic modification and resistance strategies. Genes for viral coat protein have commonly been used in the development of several virus-resistant transgenic crop plants [31, 32].

Microbial transgenes and activation of natural plant defense mechanisms. Plant biotechnologists also showed great interest in protecting vulnerable plant varieties by activating their defense responses (Table 1). While the inhibition of virulence factors is also under intense investigation, avirulence genes (Avr) in plant pathogens and their corresponding resistance genes (receptors) in the host plants have received considerable attention in the past two decades, because the products of resistance genes may directly or indirectly serve as receptors for pathogen Avr factors [33, 34]. Plants express resistance by activating appropriate signal transduction pathways, in which elicitors are the primary messengers (product of Avr) that interact with the products of the corresponding genes (receptors), thereby activating plant defense mechanisms. Elicitors are mostly encoded by pathogens themselves, while in some cases, pathogens hydrolyze the plant cell wall, and the hydrolyzed components work as elicitors or primary messengers in signal transduction $[34,35]$.

Recombinant DNA technology has revolutionized this strategy, and various plant species have been engineered for disease resistance. Several Avr and $R$ genes have been cloned successfully to transform susceptible varieties. The Xa10-like genes in rice (cultivar Nipponbare) confer disease resistance against rice bacterial blight [36]. The expression of a fungal gene encoding glucose oxidase in transgenic potato plants exhibited strong resistance to bacterial soft rot caused by Erwinia carotovora subsp. carotovora, and the disease resistance was sustained under both aerobic and anaerobic conditions of bacterial infection [37]. The treatment of plants with a bacterial peptide (flg22) representing the elicitor-active epitope of flagellin induces the expression of numerous defense-related genes and triggers resistance to pathogenic bacteria [38]. Similarly, the transformation of rice with the cht 42 gene of Trichoderma virens for enhanced resistance to sheath blight disease was also reported previously. The biocontrol of fungi in the genus Trichoderma have been reported for specific genes encoding proteins with high antifungal activities against different types of plant pathogenic fungi. Gentile et al. (2007) reported the introduction of the chit42 gene from Trichoderma harzianum into Femminello siracusano, one of the best Italian lemon cultivars. They evaluated the resistance of transgenic lemon plants to Phoma tracheiphila and Botrytis cinerea and found significantly less lesion development than that in control plants [39]. The simplest means for engineering plant resistance to fungal and bacterial diseases has been recently found to require the constitutive expression of antifungal and antibacterial genes in transgenic plants. The heterologous expression in plant-based systems is known as plant-molecular farming. In this approach, transgenic plants overexpressing genes for avirulence (avrPto), pectate lyase (PL3), tabtoxin resistance, chloroperoxidase, chitinases, $\beta-1,3$ glucanase, and polygalacturans have been shown to exhibit enhanced levels of resistance to bacterial and fungal infections or 
delayed disease symptoms in response to microbial invasion $[34,36]$.

\section{Microbial Transgenes for Abiotic Stress Mitigation and Food Quality}

Environmental stress adversely affects the growth and development of plants. Therefore, reducing the effects of environmental stressors on plant growth at the physiological level of the plant can lead to sustainable agriculture. Microbial transgenes have been considered useful to improve plant tolerance to different environmental stresses, increase desirable traits in plants, and improve food quality of crop plants $[40,41]$.

According to Quan et al. (2004), glycinebetaine, present in different microorganisms and plants, stabilizes the structure of membranes and proteins in abiotic stress conditions. Glycinebetaine also appears to be a critical determinant of stress tolerance in plants. Similarly, the exogenous application glycinebetaine enhances the growth and survival of plants under stress conditions. Transgenesis of betaine-synthesizing genes into plants lacking it has proved to be an effective way to enhance abiotic stress tolerance in such plant species. The expression of the bet $A$ gene isolated from E. coli in tobacco plants resulted in the accumulation of glycinebetaine and enhanced the salt and chilling stress tolerance [14, 42]. Similarly, Lee et al. (2014) isolated cold-shock protein gene $(\operatorname{Ar} \operatorname{Crp} A)$ from soil bacteria Arthrobacter sp. and overexpressed it in S. cerevisiae and tobacco plants. This overexpression of the $\operatorname{ArCrpA}$ gene in tobacco plants greatly contributed to abiotic stress tolerance against cold, drought and salt [43].

The synthesis of the plant hormone ethylene is affected by different factors. Ethylene stress is produced in response to flooding, drought, chemicals, metals, and phytopathogens [44]. Many transgene products that can alter ethylene synthesis and mitigate the effects of environmental stressors have been identified. The structural gene acdS is responsible for the production of ACC deaminase and has been reported from different microorganisms. Transgenic plants that express microbial acdS genes encoding 1aminocyclopropane-1-carboxylate (ACC) deaminase exhibit augmented resistance to a variety of environmental stressors, including metal contamination [45], flooding [46], salt [47] and other organic and inorganic chemicals. Grichko et al. (2000) reported the expression of the bacterial acdS gene in tomato plants under the transcriptional control of $35 S$ cauliflower mosaic virus promoters and the rolD promoter from Agrobacterium rhizogenes. The results were compared with those of non-transgenic tomato plants in their ability to grow in the presence of metal contaminants [45]. The precursor for ethylene synthesis (ACC) is converted into $\alpha$-ketobutyrate and ammonia by ACC deaminases, and the level of ethylene stress is reduced in transgenic plant tissues. Many microbial transgenes in plants have been reported thus far. Sergeeva et al. (2006) transformed Brassica napus to express the bacterial ACC deaminase (EC 4.1.99.4) gene under the transcriptional control of the $35 \mathrm{~S}$ promoter and root-specific promoter of the rolD gene within the T-DNA from the Ri plasmid of A. rhizogenes. They reported the improved salt tolerance of transgenic plants in the field, which was the ultimate result of decreased synthesis of ethylene [48]. Similarly, Serrano et al. (1998) expressed yeast regulatory genes (HAL1 and TPS1) in melon and tobacco to improve salt and drought stress tolerance [49].

Model plants such as Arabidopsis thaliana have a shorter life cycle than that of most crop plants, which is why a number of candidate genes have been screened in model transgenic plants for the rapid evaluation of a specific trait and then introduced into target crop plants. Zhu et al. (2015) cloned two bacterial glutamine synthetase genes (GSI genes) and transformed them into $A$. thaliana. The genes were expressed and markedly improved plant biomass and nitrogen utilization. They also suggested that the bacterial GS genes could be used in producing transgenic crop plants with improved growth and nitrogen-use efficiency [50]. Microbial transgenes have been reported in different crop plants for improved resistance and food quality. Classically, Bacillus thuringiensis has been used in controlling insects in the cultivation of vegetables (tomato, cabbage, cauliflower) and fruits [51, 52]. Furthermore, the use of classical procedures for pest control, such as crop rotations and chemical insecticides, might be ineffective as a result of either resistance or behavioral modifications in different crops. According to Vaughn et al. (2005), transgenic maize hybrids that control the corn rootworm are eight times more lethal to corn rootworm larvae than the wild-type protein. They created a Cry3Bb1 B. thuringiensis $(B t)$ variant containing the modified $c r y 3 B b 1$ gene in a DNA vector, placed it under the control of a root-enhanced promoter (4AS1), and introduced it into embryonic maize cells by a micro-projectile bombardment procedure. In this way, the gene encoding $B t$ toxins makes crops resistant to feeding damage by different pests, thereby enhancing the yield [53, 54]. Nuutila et al. (1999) reported the expression of fungal thermo-tolerant endo-1,4- $\beta$-glucanase in transgenic barley during germination. The fungal gene egl1, which codes for thermo-tolerant endo-1,4- $\beta$-glucanase, was transferred to 
barley cultivars (Kymppi and Golden Promise) for better brewing properties by using particle bombardment [55]. The emergence of innovative techniques and bioinformatics technologies has transformed the overall scenario of plant biotechnology, and the gene of interest can be easily identified and introduced in different crop plants for augmented activity and improved "frankenfoods."

\section{Microbial Transgenes for Beneficial Enzymes, Antibodies, and Vaccines}

Novel terms like "molecular farming," "plants as bioreactors," and "plants as living laboratories" are routinely cited in the literature. All these terms offer plant-based expression of transgenes for industrially valuable enzymes, antibodies, and vaccines. Moreover, several researchers have reported that plants can produce high-quality recombinant proteins and bioactive secondary metabolites of industrial and pharmaceutical importance. Meanwhile, industrial enzymes have been successfully produced in plants without any adverse effect on the phenotype of the plant $[56,57]$. Haldrup et al. (1998) isolated the gene $x y l A$ from Streptomyces rubiginosus, which encodes xylose isomerase, and cloned it between the enhanced CaMV-35S promoter (E35S) and terminator (35St) for developing transgenic potato plants. They selected transgenic plants with high enzyme activity on xylose and found that transgenic potato plants exhibited 5- to 25-fold higher activity of the enzyme compared to the control plants. The enzyme xylose isomerase is frequently used in the food industry [58]. Furthermore, the expression of microbial transgenes in plants provides a viable technology for the production of protein products at a low cost and with high stability and the possibility of direct addition of plant material in different industrial processes [59]. The use of heterologous enzymes is also preferred in various industrial processes because of their thermo-stability and suitable $\mathrm{pH}$. Microbial-origin $\alpha$-amylase finds a wide application in various industries because of its stability at high temperatures and over a wide $\mathrm{pH}$ range [60]. Pen et al. (1992) expressed $\alpha$-amylase of Bacillus licheniformis in tobacco. This enzyme is commonly used in starch liquefaction [61]. However, recombinant enzymes/proteins based on nuclear transformation have been found to have a low yield, which is also a major constraint of this technology. Recently, the plastome (plastid genome) has been considered advantageous for molecular farming because it uses the operon expression system, given its prokaryotic origin. Independent plastidial transcription and translation have facilitated a higher expression of recombinant genes as compared to nuclear-based expression systems [62]. More recently, Longoni et al. (2015) isolated and expressed five cellulase microbial transgenes and one polygalacturonase gene from Aspergillus niger in the tobacco chloroplast [63]. Castiglia et al. (2016) reported the expression of bacterial and archaeal genes in the tobacco plastome. They reported three genes encoding cellulolytic enzymes (endo- $\beta-1,4$-xylanase, endoglucanase, and $\beta$ glucosidase) isolated from a thermophilic bacterium (Alicyclobacillus acidocaldarius) and two hyper-thermophilic species of Archaea (Sulfolobus solfataricus and Pyrococcus furiosus), respectively. They also reported the application of plastid-based cellulolytic enzymes in the bioconversion of industrially pretreated biomass feedstock for biofuel production. Foreign antibody genes can be introduced into plants for the production of various types of antibodies [6]. Antibodies produced by transgenic plants are known as "plantibodies," which were initially reported by graduate students in Germany. Several plantibodies, vaccines, pathogenicity-related proteins, and hydrolytic enzymes (chitinase and glucanase) have also been reported from microbial transgenes in plants. Hydrolytic enzymes capable of degrading the cell wall of invading pathogenic fungi are an important component of the defense response in plants against fungal pathogens in many fruit plants [64, 65].

The high-cost and laborious recovery of biopharmaceuticals restricts their availability in the market. Owing to the advent of recent technologies, transgenic plants are utilized as bioreactors for the low-cost, large-scale generation of antibodies and vaccines with easily manageable downstream processing. The purification requirement can also be reduced by using transgenic plants containing vaccines as food $[64,66]$.

Microbial transgenes in plants have been reported for the production of different forms of IgG and IgA antibodies, including normal, chimeric, and secretory antibodies, as well as single-chain Fv fragments and Fab fragments, in the last two and half decades. Different antibodies have been successfully expressed in tobacco, rice, soybean, and potatoes. Initially, mice were used for the production of monoclonal antibodies (specific high-quality antibodies against one specific epitope). This was later critically discouraged because of immunogenicity and certain ethical complications. Moreover, it has been estimated that for plantibodies expressing up to $1 \%$ of total soluble protein, the production cost would be $0.1 \%$ of that of the animal cell culture system and up to $2-10 \%$ of that of microbial systems [66-68]. The successful production of pharmaceutical proteins in plants has laid the foundation for an innovative 
and momentous branch of plant biotechnology. Several researchers have generated many transgenic plants with their valuable products but have also revealed some limitations in different conditions, which include transgene silencing, very low expression, and altered glycosylation patterns, all of which need to be overcome in the near future $[68,69]$.

\section{Microbial Transgenes in Plants for Secondary Metabolites}

Primary metabolites are required for normal cellular functions, while secondary metabolites, secreted outside the cell, have multiple functions throughout the plant's life cycle, such as mediation in the interaction of the plant with microorganisms, insects, and other plants. Secondary metabolites are primarily involved in a plant's defense mechanism and play an important role in fertilization, for example, the production of antifeedants and phytoalexins helps in a plant's defense system, while pollinators are attracted by these metabolites for successful reproduction. Secondary metabolites are also used in the production of medicines, insecticides, and food additives [70, 71].

In several studies, the gene of interest has been isolated from microorganisms and expressed in plants for the synthesis or overexpression of a particular secondary metabolite. Carotenoids are secondary metabolites or pigments of plants. They also function as antioxidants; furthermore, vitamin A is formed from $\beta$-carotene. Shewmaker et al. (1999) isolated the bacterial phytoene synthase $(\mathrm{crtB})$ gene and overexpressed it in Brassica napus. The resultant embryos from the transgenic plants revealed the overexpression of the bacterial gene and resulted in up to a 50-fold increase in $\beta$-carotene levels. Similarly, the bacterial carotenoid gene crtI has been transferred and overexpressed in tomato plants. The $\beta$-carotene content was increased up to threefold ( $45 \%$ of the total carotenoid) by the overexpression of a bacterial phytoene desaturase in tomato plastids. The phenotype was not affected and was found to remain stable for a few generations [72]. However, the total carotenoid content, including the direct product of the enzyme lycopene, was reduced [73]. In plants, salicylic acid is derived from phenylalanine, and it enhances resistance to various pathogens, while in microorganisms, salicylic acid formed from chorismate by the enzyme isochorismate synthase (ICS) is converted to salicylic acid by isochorismate pyruvate lyase (IPL). Verberne et al. (2000) reported the transformation of tobacco plants with bacterial IPL and ICS genes. Both the genes were joined to the plant promoter, and its overexpression resulted in a 500- to 1,000-fold increase in salicylic acid compared to control plants with enhanced resistance to pathogens [74]. Zook et al. (1996) characterized sesquiterpenoid biosynthesis in Nicotiana tabacum from the expression of fungal sesquiterpene synthase. The gene encoding trichodiene synthase (Tri5), a sesquiterpene synthase isolated from Fusarium sporotrichioides, was expressed in tobacco. They also suggested that the ability to alter plant secondary metabolite production by introducing foreign genes in plants can facilitate the exploration of novel secondary metabolites [75]. Basu et al. (2017) reported the expression of the fungal gene cryptogein in Tylophora indica, which encodes a fungal elicitor protein, $\beta$-cryptogein. They used A. rhizogenes for transformation and studied the effect of the cryptogein gene on the growth, phenotype, and secondary metabolite accumulation in the co-transformed roots and plants of $T$. indica. Their results suggested that the expression of the cryptogein gene in T. indica incites the production of phenolic compounds in the transformed root and plants, while the cryptogein-transformed plants can be used as a tool to elucidate the biochemical basis of defense responses, as these secondary metabolites play important roles in defense mechanisms [76]. According to Kumar and Mitra (2017), the hairy root culture of Nicotiana tabacum infected with $A$. rhizogenes facilitates the enhanced production of secondary metabolites and can be used as a platform for genetic manipulation and the production of valuable bioactive secondary metabolites. They also reported that the versatile and flexible performance of tobacco plants in tissue culture and molecular biology renders it a model plant for genetic manipulation and the study of secondary metabolism [77].

\section{Limitations of Microbial Transgenes in Plants}

The expression of microbial transgenes in plants for different traits is one of the major outcomes of plant biotechnology. The production of various transgenic plants and their beneficial products have been reported but with some limitations. Primarily, the development of broadspectrum disease-resistant transgenic plants is hindered by variations in pathogens and their mode of action. Similarly, inadequate expression/silencing of microbial transgenes in plants and altered glycosylation patterns are the major limitations of microbial transgenes in the plant life cycle $[68,78]$. Besides this, challenges like bioethical issues, risk to the environment, and informed consent of consumers are the main concerns to be addressed before introducing such plants in the market. Generally, pathogens produce toxins and enzymes for infection, while transgenic plants 
respond by resistance to the disease condition by encoding detoxifying agents. However, sometimes, these detoxifying agents are harmful to consumers and may lead to health and environmental problems [10, 68]. There are various strategies for creating pathogen resistance in plants through genetic engineering; however, the limitations such as chances of toxicity, adverse effect on the environment, and low effectiveness should be addressed properly. Besides this, it is an uphill task to estimate the antimicrobial efficacy of the microbial transgene before plant transformation because of redundancy in transgene integration and expression level. Finally, a very pertinent question yet to be answered is with respect to the consequences of the evolution of pathogens and the spread of virulent diseases in response to the resistance to microbial pathogens through genetic engineering, because the choice of a microbial transgene for expression in plants has obvious consequences on native microbial populations. Despite many ethical and environmental concerns, several plants have been transformed by introducing microbial transgenes to yield green bioreactors or living laboratories for valuable products. Furthermore, certain microbial transgenes have been introduced to develop disease-resistant plants against fungal, bacterial, and viral pathogens. The details of some microbial transgenes and their roles are listed in Table 1. Furthermore, plant biotechnologists are trying to introduce novel strategies and techniques to overcome different issues and experimental hurdles.

\section{Targeted Genome Editing Technology and Genetically Modified Plants}

Since the last two decades, genetic engineering of plants has expanded dramatically, and significant numbers of genetically modified plants and their products have been produced all over the world. Recently, researchers have focused on plants for the production of different metabolites, antibodies, vaccines, fruits with extended shelf-life, and plants with increased resistance against pathogens. However, successful development seemed unattainable because of public concerns and lack of consumer acceptance of genetically modified crops and their products, which were the main hindrances in the process of commercialization. Nevertheless, some genetically modified plants and their products with new traits and better characteristics have become commercialized in Asia and other third world countries. However, due to health and environmental safety concerns, European countries politicized the issue and imposed restrictions on the production of genetically modified plants and their products $[79,80]$. More recently, the advances in targeted genome editing technology and introduction of novel techniques such as clustered regularly interspaced short palindromic repeats (CRISPR/Cas) has revolutionized the process of genetic modification. Plant genomes can now be edited very precisely, and transgenes can be knocked out or replaced in the final transgenic plant line [18-20, 79]. This significant concept of genome editing technology is anticipated to diminish the opinion gap and change consumer attitude toward genetically modified plants and their products. CRISPR/Cas is a simpler and more accurate technique compared with previous methods such as zinc finger nucleases and the transcription activatorlike effector nuclease system (TALENS) [80, 81]. Doudna and Charpentier provided a detailed interpretation of the CRISPR/Cas9 system in 2014 [19], and some of the genes have been successfully edited in model and crop plants (soybean, Arabidopsis, barley, Brassica, rice, and maize) by using the CRISPR/Cas9 system [82, 83, 84]. CRISPR was initially identified in E. coli, and the detailed mechanisms of the CRISPR/Cas9 system have been reported. CRISPR/ Cas 9 consists of DNA-specific nucleases that cut DNA at a particular site [85]. The double-stranded break is created at a precise location at $20 \mathrm{bp}$ and repaired by the nonhomologous end-joining repair mechanism that places the cut ends together; the nearby sequences may be repaired by the homologous repair mechanism [86]. A single plasmid can be inserted with high copy numbers of the new and defined sequences into the double-stranded break, while a larger sequence can also be removed. In gene editing, only a few base pairs can be changed at a particular site, while in genetic modification, a slightly larger sequence is derived from a different species, such as a microbial source, and inserted into plants. Khatodia et al. (2016) reported the widespread applications of CRISPR/Cas as a genome editing tool in crop improvement. They also indicated that the applicability of the native Cas9/sgRNA system has been revealed in different model and crop plants for targeted mutagenesis, gene knockouts and replacement, and multiplex plant gene editing systems [79]. The effectiveness of the CRISPR/Cas technology as a plant genome editing system will not only increase plant growth and productivity but will also change the attitude of consumers for the acceptance of genetically modified plants and their products in the future.

\section{Outlook and Future Prospects}

Since three decades, the considerable progress made in 
the field of plant biotechnology has set the stage for genetic engineering and targeted genome editing of model and crop plants. Numerous sophisticated procedures have been adopted for genetic manipulation and the production of improved varieties with desirable traits. The advancements in this field have also enabled the genetic modification of metabolic pathways and have led to the achievement of a number of different bioactive secondary metabolites, antibodies, vaccines, and resistant transgenic plants. Traditionally, crops and their yields were being improved by conventional breeding and genetic engineering, the applicability of which is now fading because of the limit of the pre-existing genetic variation in different crop plants. The introduction of new traits and improved characteristics in genetically modified plants and their products is therefore acknowledged as a means for expanding the genetic base of species. While the development of new techniques such as targeted genome editing systems has revolutionized the field of molecular farming, these tools have also enabled researchers to introduce very precise genetic modifications in plant genomes in an easy and efficient way.

Recently, a number of microbial genes have been identified for the production of valuable secondary metabolites and antimicrobial compounds. Similarly, different transgenes have been used for conferring infections and disease resistance in crop plants. However, it is imperative to redefine the prevailing methodologies and develop novel strategies for desirable traits and disease resistance. The identification of unknown defense-eliciting genes [87], the use of synthetic promoters for better transcriptional regulation of transgene expression in plants [88], and the details of molecular signaling and recognition events will contribute to the existing research. Scott in 1994 reviewed genetically engineered cereals (wheat, barley, maize, rice, and oats), the successful production of fertile transgenic plants, and their resistance to various phytopathogens [89]. In the same manner, [1] reviewed bacterial and fungal transgene expression in different transgenic plants, with the main focus on the applications of microbial transgenes in plants for improved resistance to bacterial, viral, and fungal diseases. In addition, they also highlighted different environmental concerns and biosafety queries resulting from the transgenesis. The potential application of genetically engineered plants and their products leads the way for effective solutions for global food security, and a number of different model and crop plants have been genetically modified for high yield and other valuable products.

Despite the enormous applications and productivity of microbial transgenes in genetically engineered plants and their products, different European communities have raised their concerns regarding ethical, health, and environmental issues, which led to the imposition of restrictions on the commercialization of genetically modified plants and their products. However, the advancement in molecular biology techniques introduced targeted genome editing systems, which allow the removal or replacement of transgenes in the final line of transgenic plants [19, 20]. The research of Jia et al. (2017) revealed that genome editing tools (CRISPR/ Cas9/sgRNA technology) could be used to modify the canker susceptibility gene CsLOB1 in Duncan grapefruit and also suggested that this system will provide a promising corridor for the production of different diseaseresistant varieties [18]. Khatodia et al. in 2016 published a review paper on the broad-level applicability of the Cas 9 nuclease-mediated targeted genome editing system for the development of designed crop plants. They also revealed the prospects of the gene editing with Cas9/sgRNA for different characteristics, such as plants with greater adaptability in adverse environments, and plants for bioenergy production, as well as for the social acceptance of the designed plants. In addition, CRISPRi (CRISPR interference) and CRISPRa (CRISPR activator) have been revealed for guide RNA repression and modulation of gene expression, respectively, while their libraries will be extremely helpful in functional genomics analysis, as these are powerful tools for mapping signaling pathways in plants under stress conditions. Formerly, the methods of genetic variations and random mutagenesis were used for the introduction of new traits into cultivated varieties, while the CRISPR/Cas system can incorporate specific and stable changes in the plant genome. The most fascinating aspect of this system is the removal of microbial transgenes after the editing of the targeted region, thereby freeing the plants of transgenes during crop variety improvement [20, 79, 90].

With the advancements in the field of plant biotechnology and novel high-precision techniques such as targeted genome editing tools (CRISPR/Cas9), the editing of genes has become a significant tool and is being increasingly reported by different research groups around the world. Since its inception almost five years ago, researchers have shown great interest to tweak the genome with high specificity and greater ease compared to other available techniques. Researchers have come up with different ways to edit the genome by using CRISPR/Cas9, and yet, some limitations remain, such as editing at a single point [91, 92]. In a more recent report, Ledford suggested that the efficiency of the Cas9 protein can be improved and allowed 
to act and cut more sites next to the protospacer adjacent motif in the genome with fewer undesirable effects [93]. Thus, constantly evolving methods and technologies will continue to answer the ever-growing problems of food shortage and malnutrition all over the world. Scientists are expected to continue to update valuable techniques and infrastructure for the efficient productivity of crop plants for controlling food scarcity and hunger in the burgeoning population on our planet.

\section{Acknowledgments}

This work was carried out with the support of "Cooperative Research Program for Agriculture Science \& Technology Development (Project No. PJ01369001)" Rural Development Administration, Republic of Korea.

\section{Conflict of Interest}

The authors have no financial conflicts of interest to declare.

\section{References}

1. Rai MK, Shekhawat NS. 2014. Recent advances in genetic engineering for improvement of fruit crops. Plant Cell Tissue Organ Culture 116: 1-15.

2. Lorito M, Scala F. 1999. Microbial genes expressed in transgenic plants to improve disease resistance. J. Plant Pathol. 81: 73-88.

3. Broothaerts W, Mitchell HJ, Weir B, Kaines S, Smith LM, Yang W, et al. 2005. Gene transfer to plants by diverse species of bacteria. Nature 433: 629-633.

4. Tobias CM, Oldroyd GE, Chang JH, Staskawicz BJ. 1999. Plants expressing the Pto disease resistance gene confer resistance to recombinant PVX containing the avirulence gene AvrPto. Plant J. 17: 41-50.

5. Kasukabe Y, He L, Nada K, Misawa S, Ihara I, Tachibana S. 2004. Overexpression of spermidine synthase enhances tolerance to multiple environmental stresses and upregulates the expression of various stress-regulated genes in transgenic Arabidopsis thaliana. Plant Cell Physiol. 45: 712-722.

6. Castiglia D, Sannino L, Marcolongo L, Ionata E, Tamburino R, Stradis A, et al. 2016. High-level expression of thermostable cellulolytic enzymes in tobacco transplastomic plants and their use in hydrolysis of an industrially pretreated Arundo donax L. biomass. Biotechnol. Biofuels 9: 154.

7. Yang YY, Mei F, Zhang W, Shen Z, Fang J. 2014. Creation of Bt rice expressing a fusion protein of Cry1Ac and Cry1Ilike using a green tissue-specific promoter. J. Econ Entomol.
107: 1674-1679.

8. Yang L, Hu C, Li N, Zhang J, Yan J, Deng Z. 2011. Transformation of sweet orange [Citrus sinensis (L.) Osbeck] with pthA-nls for acquiring resistance to citrus canker disease. Plant Mol. Biol. 75: 11-23.

9. Guan ZJ, Guo B, Hao HY, Huo YL, Dai JK, Wei YH. 2012. Expression of hepatitis B surface antigen (HBsAg) gene in transgenic cherry tomato. African J. Biotechnol. 11: 7186-7192.

10. Collinge DB, Jorgensen HJ, Lund OS, Lyngkjaer MF (2010). Engineering pathogen resistance in crop plants: current trends and future prospects. Annu. Rev. Phytopathol. 48: 269-291.

11. Farwell AJ, Vesely S, Nero V, Rodriguez H, McCormack K, Shah S, et al. 2007. Tolerance of transgenic canola plants (Brassica napus) amended with plant growth-promoting bacteria to flooding stress at a metal-contaminated field site. Environ. Pollut. 147: 540-545.

12. Grichko VP, Glick BR. 2001. Flooding tolerance of transgenic tomato plants expressing the bacterial enzyme ACC deaminase controlled by the $35 \mathrm{~S}$, rolD or PRB- $1 b$ promoter. Plant Physiol. Biochem. 39: 19-25.

13. Bordas M, Montesinos C, Dabauza M, Salvador A, Roig LA, Serrano R, et al. 1997. Transfer of the yeast salt tolerance gene HAL1 to Cucumis melo L. cultivars and in vitro evaluation of salt tolerance. Transgenic Res. 6: 41-50.

14. Quan R, Shang M, Zhang H, Zhao Y, Zhang J. 2004. Improved chilling tolerance by transformation with betA gene for the enhancement of glycinebetaine synthesis in maize. Plant Sci. 166: 141-149.

15. Tacket CO, Mason HS, Losonsky G, Clements JD, Levine MM, Arntzen CJ. 1998. Immunogenicity in humans of a recombinant bacterial antigen delivered in a transgenic potato. Nat. Med. 4: 607-609.

16. Kim DS, Lee SH, Ko K. 2015. Expression and function of plant-derived recombinant multiple monoclonal antibodies for the recognition of human colorectal cancer cells. Plant Biotechnol. Rep. 9: 361-368.

17. Gambino G, Gribaudo I. 2012. Genetic transformation of fruit trees: current status and remaining challenges. Transgenic Res. 21: 1163-1181

18. Jia $\mathrm{H}$, Zhang $\mathrm{Y}$, Orbović $\mathrm{V}, \mathrm{Xu}$ J, White FF, Jones JB, Wang $\mathrm{N}$. 2017. Genome editing of the disease susceptibility gene CsLOB1 in citrus confers resistance to citrus canker. Plant Biotechnol. J. 15: 817-823.

19. Doudna JA, Charpentier E. 2014. The new frontier of genome engineering with CRISPR-Cas9. Science 346: 346(6213): 1258096.

20. Mahfouz MM, Piatek A, Stewart CN. 2014. Genome engineering via TALENs and CRISPR/Cas9 systems: challenges and perspectives. Plant Biotechnol. J. 12: 1006-1014.

21. Ab Rahman SFS, Singh E, Pieterse CM, Schenk PM. 2017. Emerging microbial biocontrol strategies for plant pathogens. Plant Sci. 267: 102-111. 
22. Savary S, Ficke A, Aubertot JN, Hollier C. 2012. Crop losses due to diseases and their implications for global food production losses and food security. Food Security 4: 519-537.

23. Dehestani A, Kazemitabar K, Ahmadian G, Jelodar NB, Salmanian AH, Seyedi M, et al. 2010. Chitinolytic and antifungal activity of a Bacillus pumilus chitinase expressed in Arabidopsis. Biotechnol. Lett. 32: 539-546.

24. Khan A, Nasir IA, Tabassum B, Aaliya K, Tariq M, Rao AQ. 2017. Expression studies of chitinase gene in transgenic potato against Alternaria solani. Plant Cell Tissue Organ. Culture. 128: 563-576.

25. Kovacs G, Sagi L, Jacon G, Arinaitwe G, Busogoro JP, Thiry E, et al. 2013. Expression of a rice chitinase gene in transgenic banana ('Gros Michel', AAA genome group) confers resistance to black leaf streak disease. Transgenic Res. 22: 117-130.

26. Expression of bacterial chitinase protein in tobacco leaves using two photosynthetic gene promoters. Mol. General Genetics MGG 212: 536-542.

27. Kahlon JG, Jacobsen HJ, Cahill JF, Hall LM. 2017. Antifungal genes expressed in transgenic pea (Pisum sativum L.) do not affect root colonization of arbuscular mycorrhizae fungi. Mycorrhiza 27: 683-694.

28. Anzai H, Yoneyama K, Yamaguchi I. 1989. Transgenic tobacco resistant to a bacterial disease by the detoxification of a pathogenic toxin. Mol. General Genetics MGG 219: 492-494.

29. Mourgues F, Brisset MN, Chevreau E. 1998. Strategies to improve plant resistance to bacterial diseases through genetic engineering. Trends Biotechnol. 16: 203-210.

30. Castillo E, Martinelli F, Zakharov-Negre F, Ebeler SE, Buzo TR, McKenry MV, et al. 2017. Effects of transgenic expression of Brevibacterium linens methionine gamma lyase (MGL) on accumulation of Tylenchulus semipenetrans and key aminoacid contents in Carrizo citrange. Plant Mol. Biol. 95: 497-505.

31. Dasgupta I, Malathi VG, Mukherjee SK. 2003. Genetic engineering for virus resistance. Curr. Sci. 84: 341-354.

32. Kung YJ, Bau HJ, Wu YL, Chen TM, Su WC, Yeh SD. 2009. Generation of transgenic papaya resistant to Papaya ringspot virus and Papaya leaf distortion mosaic virus. Phytopathology 99: 1312-1320.

33. Staskawicz BJ. 2001. Genetics of plant-pathogen interactions specifying plant disease resistance. Plant Physiol. 125: 73-76.

34. Kashyap PL, Sanghera GS, Shabir HW, Shafi W, Kumar S, Srivastava AK, et al. 2011. Genes of microorganisms: paving way to tailor next generation fungal disease resistant crop plants. Notulae Scientia Biologicae 3: 147-157.

35. Kombrink E, Somssich IE. 1995. Defense Responses of Plants to Pathogens. vol. 21, pp. 1-34. In Advances in botanical research. Academic Press.

36. Wang J, Tian D, Gu K, Yang X, Wang L, Zeng X, et al. 2017. Induction of Xa10-like genes in rice cultivar nipponbare confers disease resistance to rice bacterial blight. Mol. Plant Microbe Interact. 30: 466-477.

37. Wu G, Shortt BJ, Lawrence EB, Levine EB, Fitzsimmons KC, Shah DM. 1995. Disease resistance conferred by expression of a gene encoding $\mathrm{H} 2 \mathrm{O} 2$-generating glucose oxidase in transgenic potato plants. Plant Cell 7: 1357-1368.

38. Zipfel C, Robatzek S, Navarro L, Oakeley EJ, Jones JD, Felix G, et al. 2004. Bacterial disease resistance in Arabidopsis through flagellin perception. Nature 428: 764767.

39. Gentile A, Deng Z, La Malfa S, Distefano G, Domina F, Vitale A, et al. 2007. Enhanced resistance to Phoma tracheiphila and Botrytis cinerea in transgenic lemon plants expressing a Trichoderma harzianum chitinase gene. Plant Breeding 126: 146-151.

40. Reed GL, Jensen AS, Riebe J, Head G, Duan, J. J. 2001. Transgenic Bt potato and conventional insecticides for Colorado potato beetle management: comparative efficacy and non-target impacts. Entomologia Exp. Appl. 100: 89-100.

41. Sharma HC, Sharma KK, Crouch JH. 2004. Genetic transformation of crops for insect resistance: potential and limitations. CRC Crit. Rev. Plant Sci. 23: 47-72.

42. Holmström KO, Somersalo S, Mandal A, Palva TE, Welin B 2000. Improved tolerance to salinity and low temperature in transgenic tobacco producing glycine betaine. J. Exp. Bot. 51: $177-185$

43. Lee SK, Park SH, Lee JW, Lim HM, Jung SY, Park IC, Park SC. 2014. A putative cold shock protein-encoding gene isolated from Arthrobacter sp. A2-5 confers cold stress tolerance in yeast and plants. J. Korean Soc. Appl. Biol. Chem. 57: 775-782.

44. Glick BR. 2014. Bacteria with ACC deaminase can promote plant growth and help to feed the world. Microbiol. Res. 169: 30-39.

45. Grichko VP, Filby B, Glick BR. 2000. Increased ability of transgenic plants expressing the bacterial enzyme ACC deaminase to accumulate $\mathrm{Cd}, \mathrm{Co}, \mathrm{Cu}, \mathrm{Ni}, \mathrm{Pb}$, and $\mathrm{Zn}$. J. Biotechnol. 81: 45-53.

46. Glick BR, Cheng Z, Czarny J, Duan J. 2007. Promotion of plant growth by ACC deaminase-producing soil bacteria. Eur. J. Plant Pathol. 119: 329-339.

47. Mayak S, Tirosh T, Glick BR. 2004. Plant growth-promoting bacteria confer resistance in tomato plants to salt stress. Plant Physiol. Biochem. 42: 565-572.

48. Sergeeva E, Shah S, Glick BR. 2006. Growth of transgenic canola (Brassica napus cv. Westar) expressing a bacterial 1aminocyclopropane-1-carboxylate (ACC) deaminase gene on high concentrations of salt. World J. Microbiol. Biotechnol. 22: 277-282.

49. Serrano R, Culiañz-Maciá FA, Moreno V. 1998. Genetic engineering of salt and drought tolerance with yeast regulatory genes. Sci. Hortic. 78: 261-269.

50. Zhu C, Zhang G, Shen C, Chen S, Tang Y, Mei B, Song R. 2015. Expression of bacterial glutamine synthetase gene in 
Arabidopsis thaliana increases the plant biomass and level of nitrogen utilization. Biologia 70: 1586-1596.

51. Barboza-Corona JE, De la Fuente-Salcido NM, León-Galván MF. 2012. Future challenges and prospects of Bacillus thuringiensis. Bacillus thuringiensis Biotechnology. Springer Netherlands. 3: 367-384.

52. Prado JR, Segers G, Voelker T, Carson D, Dobert R, Phillips J, et al. 2014. Genetically engineered crops: from idea to product. Annu. Rev. Plant Biol. 65: 769-790.

53. Vaughn T, Cavato T, Brar G, Coombe T, DeGooyer T, Ford S, et al. 2005. A method of controlling corn rootworm feeding using a Bacillus thuringiensis protein expressed in transgenic maize. Crop Sci. 45: 931-938.

54. Walters FS, Stacy CM, Lee MK, Palekar N, Chen JS. 2008. An engineered chymotrypsin/cathepsin G site in domain I renders Bacillus thuringiensis Cry3A active against western corn rootworm larvae. Appl. Environ. Microbiol. 74: 367-374.

55. Nuutila AM, Ritala A, Skadsen RW, Mannonen L, Kauppinen V. 1999. Expression of fungal thermotolerant endo-1, 4- $\beta$-glucanase in transgenic barley seeds during germination. Plant Mol. Biol. 41: 777-783.

56. Goddijn OJ, Pen J. 1995. Plants as bioreactors. Trends Biotechnol. 13: 379-387.

57. Sack M, Rademacher T, Spiegel H, Boes A, Hellwig S, Drossard J, et al. 2015. From gene to harvest: insights into upstream process development for the GMP production of a monoclonal antibody in transgenic tobacco plants. Plant Biotechnol. J. 13: 1094-1105.

58. Haldrup A, Petersen SG, Okkels FT. 1998. Positive selection: a plant selection principle based on xylose isomerase, an enzyme used in the food industry. Plant Cell Rep. 18: 76-81.

59. Hood EE. 2002. From green plants to industrial enzymes. Enzyme Microbial Technol. 30: 279-283.

60. Schwardt E. 1990. Production and use of enzymes degrading starch and some other polysaccharides. Food Biotechnol. 4: 337-351.

61. Pen J, van Ooyen AJ, van den Elzen PJ, Quax WJ, Hoekema A. 1992. Efficient production of active industrial enzymes in plants. Ind. Crops Prod. 1: 241-250.

62. Reddy VS, Leelavathi S, Selvapandiyan A, Raman R, Giovanni F, Shukla V, et al. 2002. Analysis of chloroplast transformed tobacco plants with cry1Ia5 under rice psbA transcriptional elements reveal high level expression of $\mathrm{Bt}$ toxin without imposing yield penalty stable inheritance of transplastome. Mol. Breeding 9: 259-269.

63. Longoni P, Leelavathi S, Doria E, Reddy VS, Cella R. 2015. Production by tobacco transplastomic plants of recombinant fungal and bacterial cell-wall degrading enzymes to be used for cellulosic biomass saccharification. Biomed. Res. Int. 2015: 289759.

64. Hiatt A, Caffferkey R, Bowdish K. 1989. Production of antibodies in transgenic plants. Nature 342: 76-78.
65. Richter LJ, Thanavala Y, Arntzen CJ, Mason HS. 2000. Production of hepatitis B surface antigen in transgenic plants for oral immunization. Nat. Biotechnol. 18: 1167-1171.

66. Daniell H, Streatfield SJ, Wycoff K. 2001. Medical molecular farming: production of antibodies, biopharmaceuticals and edible vaccines in plants. Trends Plant Sci. 6: 219-226.

67. Stöger E, Vaquero C, Torres E, Sack M, Nicholson L, Drossard J, Fischer R. 2000. Cereal crops as viable production and storage systems for pharmaceutical scFv antibodies. Plant Mol. Biol. 42: 583-590.

68. Besufekad Y, Malaiyarsa P. 2017. Production of monoclonal antibodies in transgenic plants. J. Adv. Biol. Biotechnol. 12: $1-8$.

69. Warzecha H, Mason HS. 2003. Benefits and risks of antibody and vaccine production in transgenic plants. J. Plant Physiol. 160: 755-764.

70. Verpoorte R, Memelink J. 2002. Engineering secondary metabolite production in plants. Curr. Opin. Biotechnol. 13: 181-187.

71. Dixon RA. 2001. Natural products and plant disease resistance. Nature 411: 843-847.

72. Shewmaker CK, Sheehy JA, Daley M, Colburn S, Ke DY. 1999. Seed?specific overexpression of phytoene synthase: increase in carotenoids and other metabolic effects. Plant J. 20: 401-412.

73. Romer S, Fraser PD, Kiano JW, Shipton CA, Misawa N, Schuch W, et al. 2000. Elevation of the provitamin A content of transgenic tomato plants. Nat. Biotechnol. 18: 666-669.

74. Verberne MC, Verpoorte R, Bol JF, Mercado-Blanco J, Linthorst HJ. 2000. Overproduction of salicylic acid in plants by bacterial transgenes enhances pathogen resistance. Nat. Biotechnol. 18: 779-783.

75. Zook M, Hohn T, Bonnen A, Tsuji J, Hammerschmidt R. 1996. Characterization of novel sesquiterpenoid biosynthesis in tobacco expressing a fungal sesquiterpene synthase. Plant Physiol. 112: 311-318.

76. Basu A, Roychowdhury D, Joshi RK, Jha S. 2017. Effects of cryptogein gene on growth, phenotype and secondary metabolite accumulation in co-transformed roots and plants of Tylophora indica. Acta Physiol. Plant 39: 1-3.

77. Kumar M, Mitra A. 2017. Hairy Root Culture of Nicotiana tabacum (Tobacco) as a Platform for Gene Manipulation of Secondary Metabolism. pp.145-163. In Production of Plant Derived Natural Compounds through Hairy Root Culture Springer, Cham.

78. Punja ZK. 2001. Genetic engineering of plants to enhance resistance to fungal pathogens-a review of progress and future prospects. Can. J. Plant Pathol. 23: 216-235.

79. Khatodia S, Bhatotia K, Passricha N, Khurana SMP, Tuteja N. 2016. The CRISPR/Cas genome-editing tool: application in improvement of crops. Front. Plant Sci. 7: 506.

80. Georges F, Ray H. 2017. Genome editing of crops: a renewed 
opportunity for food security. GM Crops Food 8: 1-12.

81. Abdallah NA, Prakash CS, McHughen AG. 2015. Genome editing for crop improvement: challenges and opportunities. GM Crops Food 6: 183-205.

82. Schiml S, Fauser F, Puchta H. 2014. The CRISPR/Cas system can be used as nuclease for in planta gene targeting and as paired nickases for directed mutagenesis in Arabidopsis resulting in heritable progeny. Plant J. 80: 1139-1150.

83. Lawrenson T, Shorinola O, Stacey N, Li C, Østergaard L, Patron $\mathrm{N}$, et al. 2015. Induction of targeted, heritable mutations in barley and Brassica oleracea using RNAguided Cas9 nuclease. Genome Biol. 16: 258.

84. Svitashev S, Young J, Schwartz C, Gao H, Falco SC, Cigan AM. 2015. Targeted mutagenesis, precise gene editing and site-specific gene insertion in maize using Cas9 and guide RNA. Plant Physiol. 169: 931-945.

85. Hsu PD, Lander ES, Zhang F. 2014. Development and applications of CRISPR-Cas9 for genome engineering. Cell 157: $1262-1278$.

86. Jiang W, Bikard D, Cox D, Zhang F, Marraffini LA. 2013. RNA-guided editing of bacterial genomes using CRISPRCas systems. Nat. Biotechnol. 31: 233-239.

87. Zhang Y, Zhang Y, Qiu D, Zeng H, Guo L, Yang X. 2015. BcGs1, a glycoprotein from Botrytis cinerea, elicits defence response and improves disease resistance host plants. Biochemical and biophysical research communications. 457: 627-634.

88. Liu W, Stewart CN. 2016. Plant synthetic promoters and transcription factors. Curr. Opin. Biotechnol. 37: 36-44.

89. Scott KJ. 1994. Genetic engineering of cereals for resistance to phytopathogens. Australas Plant Pathol. 23: 154-162.

90. Gilbert LA, Larson MH, Morsut L, Liu Z, Brar GA, Torres SE, et al. 2013. CRISPR-mediated modular RNA-guided regulation of transcription in eukaryotes. Cell 154: 442-451.

91. Elie Dolgin. 2017. CRISPR hacks enable pinpoint repairs to genome. Nature 550:439-440

92. Ledford H. 2018. Powerful enzyme could make CRISPR gene-editing more versatile. Nature DOI: 10.1038/d41586018-02540-x

93. Bortesi L, Fischer R. 2015. The CRISPR/Cas9 system for plant genome editing and beyond. Biotechnol. Adv. 33: 41-52.

94. Hu CH, Wei YR, Huang YH, Yi GJ. 2013. An efficient protocol for the production of chit42 transgenic Furenzhi banana (Musa spp. AA group) resistant to Fusarium oxysporum. In Vitro Cell Dev. Biol. Plant 49: 584-592.

95. Mercado JA, Barceló M, Pliego C, Rey M, Caballero JL, Muñoz-Blanco J, et al. 2015. Expression of the $\beta-1$, 3glucanase gene bgn13. 1 from Trichoderma harzianum in strawberry increases tolerance to crown rot diseases but interferes with plant growth. Transgenic Res. 24: 979-989.

96. Ichikawa H, Kato K, Mochizuki A, Shinoyama H, Mitsuhara I. 2015. Transgenic Chrysanthemums (Chrysanthemum morifolium Ramat.) Carrying both Insect and Disease Resistance. In XXV International EUCARPIA Symposium Section Ornamentals: Crossing Borders 1087: 485-497.

97. Daniell H, Lee SB, Panchal T, Wiebe PO. 2001. Expression of the native cholera toxin $\mathrm{B}$ subunit gene and assembly as functional oligomers in transgenic tobacco chloroplasts1. J. Mol. Biol. 311: 1001-1009.

98. Nochi T, Takagi H, Yuki Y, Yang L, Masumura T, Mejima M, et al. 2007. Rice-based mucosal vaccine as a global strategy for cold-chain-and needle-free vaccination. Proc. Natl. Acad. Sci. USA 104: 10986-10991.

99. Martínez CA, Topal E, Giulietti AM, Talou JR, Mason H. 2010. Exploring different strategies to express Dengue virus envelope protein in a plant system. Biotechnol. Lett. 32: $867-875$.

100. Mohanty A, Kathuria H, Ferjani A, Sakamoto A, Mohanty P, Murata N, et al. 2002. Transgenics of an elite indica rice variety Pusa Basmati 1 harbouring the $\operatorname{cod} \mathrm{A}$ gene are highly tolerant to salt stress. Theor. Appl. Genet. 106: 51-57.

101. Kimura T, Mizutani T, Tanaka T, Koyama T, Sakka K, Ohmiya K. 2003. Molecular breeding of transgenic rice expressing a xylanase domain of the xynA gene from Clostridium thermocellum. Appl. Microbiol. Bbiotechnol. 62: 374-379.

102. Gisbert C, Rus AM, Bolarín MC, López-Coronado JM, Arrillaga I, Montesinos C, et al. 2000. The yeast HAL1 gene improves salt tolerance of transgenic tomato. Plant Physiol. 123: 393-402.

103. Li J, Hegeman CE, Hanlon RW, Lacy GH, Denbow DM, Grabau EA. 1997. Secretion of active recombinant phytase from soybean cell-suspension cultures. Plant Physiol. 114: 1103-1111.

104. Haq TA, Mason HS, Clements JD, Arntzen CJ. 1995. Oral immunization with a recombinant bacterial antigen produced in transgenic plants. Science 268: 714-716.

105. Köhle A, Sommer S, Li SM, Schilde-Rentschler L, Ninnemann H, Heide L. 2003. Secondary metabolites in transgenic tobacco and potato: high accumulation of 4hydroxybenzoic acid glucosides results from high expression of the bacterial gene ubiC. Mol. Breed. 11: 15-24.

106. Siebert M, Sommer S, Li SM, Wang ZX, Severin K, Heide L. 1996. Genetic engineering of plant secondary metabolism (accumulation of 4-hydroxybenzoate glucosides as a result of the expression of the bacterial ubic gene in tobacco). Plant Physiol. 112: 811-819.

107. Keller H, Pamboukdjian N, Ponchet M, Poupet A, Delon R, Verrier JL, et al. 1999. Pathogen-induced elicitin production in transgenic tobacco generates a hypersensitive response and nonspecific disease resistance. Plant Cell 11: 223-235.

108. Lv S, Yang A, Zhang K, Wang L, Zhang J. 2007. Increase of glycinebetaine synthesis improves drought tolerance in cotton. Mol. Breed. 20: 233-248.

109. Mozes-Koch R, Gover O, Tanne E, Peretz Y, Maori E, 
Chernin L, et al. 2012. Expression of an entire bacterial operon in plants. Plant Physiol. 158: 1883-1892.

110. Baranski R, Klocke E, Nothnagel T. 2007. Enhancing resistance of transgenic carrot to fungal pathogens by the expression of Pseudomonas fluorescence microbial factor 3 (MF3) gene. Physiol. Mol. Plant Pathol. 71: 88-95.

111. De Cosa B, Moar W, Lee SB, Miller M, Daniell H. 2001. Overexpression of the $\mathrm{Bt}$ cry2Aa2 operon in chloroplasts leads to formation of insecticidal crystals. Nat. Biotechnol. 19: $71-74$

112. Hasunuma T, Miyazawa SI, Yoshimura S, Shinzaki Y, Tomizawa KI, Shindo K, et al. 2008. Biosynthesis of astaxanthin in tobacco leaves by transplastomic engineering. Plant J. 55: 857-868.

113. Azadi P, Otang NV, Chin DP, Nakamura I, Fujisawa M, Harada $\mathrm{H}$, et al. 2010. Metabolic engineering of Lilium $\times$ formolongi using multiple genes of the carotenoid biosynthesis pathway. Plant Biotechnol. Rep. 4: 269-280.
114. Davoodi?Semiromi A, Schreiber M, Nalapalli S, Verma D, Singh ND, Banks RK, et al. 2010. Chloroplast-derived vaccine antigens confer dual immunity against cholera and malaria by oral or injectable delivery. Plant Biotechnol. J. 8: 223-242.

115. Shah JM, Raghupathy V, Veluthambi K. 2009. Enhanced sheath blight resistance in transgenic rice expressing an endochitinase gene from Trichoderma virens. Biotechnol. Lett. 31: 239-244.

116. Goel D, Singh AK, Yadav V, Babbar SB, Murata N, Bansal KC. 2011. Transformation of tomato with a bacterial codA gene enhances tolerance to salt and water stresses. J. Plant Physiol. 168: 1286-1294.

117. Wang L, Samac DA, Shapir N, Wackett LP, Vance CP, Olszewski NE, et al. 2005. Biodegradation of atrazine in transgenic plants expressing a modified bacterial atrazine chlorohydrolase (atzA) gene. Plant Biotechnol. J. 3: 475-486. 